\title{
CHARACTERISTICS OF DYNAMIC MUTATION IN JAPANESE MYOTONIC DYSTROPHY
}

\author{
Hidehisa Yamagata, ${ }^{1}$ Tetsuro Miki, ${ }^{1,}{ }^{*}$ Naoki YamanaKa, ${ }^{1}$ \\ Yuji Takemoto, ${ }^{1}$ Fumio Kanda, ${ }^{2}$ Keiichi TakahashI, ${ }^{2}$ \\ Toshio Inui, ${ }^{3}$ Masanobu Kinoshita, ${ }^{4}$ Masanori NaKagaWa, ${ }^{5}$ \\ Itsuro HiguchI, ${ }^{5}$ Mitsuhiro Osame, ${ }^{5}$ and Toshio Ogihara ${ }^{1}$ \\ ${ }^{1}$ Department of Geriatric Medicine, Osaka University Medical School, Suita, Osaka 565, Japan \\ ${ }^{2}$ Department of Neurology, Hyogo-Chuo National Hospital, Hyogo 669-13, Japan \\ ${ }^{3}$ Department of Neurology, National Sanatorium Tokushima Hospital, Tokushima 776, Japan \\ ${ }^{4}$ Fourth Department of Internal Medicine, Saitama Medical Center, Saitama 350, Japan \\ ${ }^{5}$ Third Department of Internal Medicine, Faculty of Medicine, \\ Kagoshima University, Kagoshima 890, Japan
}

Summary To study the characteristics, if any, of unstable CTG repeat sequence in Japanese myotonic dystrophy (DM), we analyzed DNA from 351 at risk individuals (including affected and non-affected carriers and their descendants) from 105 families in Japan. A total of $93 \mathrm{DM}$ families (196 affected and 116 unaffected individuals), including 84 DM parentchild pairs (44 father-child and 40 mother-child pairs), were examined, many of which had been previously tested by linkage analysis. We detected unstable CTG repeat mutations between $0.15 \mathrm{~kb}$ and $8.7 \mathrm{~kb}$ in size. The size of the mutation correlated with the age of onset of symptoms. There was a significant difference in DM allele size among the four groups (congenital, juvenile onset, classical, and minimal). Congenital DM had on average the largest repeat sizes. Comparison of parent-child pairs showed that most offspring had a larger repeat size than their parents, with only 2 of 84 showing a definite decrease in repeat size. The correlation coefficients for maternal and paternal transmission were 0.41 and 0.15 , respectively. The parental age (maternal and paternal) did not correlate with intergenerational change of repeat. These observations are similar to those reported in Caucasians.

Key Words myotonic dystrophy, unstable CTG repeat sequence, anticipation, dynamic mutation, contraction

Received May 6, 1994; Revised version accepted June 10, 1994.

*To whom correspondence should be addressed. 


\section{INTRODUCTION}

Myotonic dystrophy (DM) is an autosomal dominant, multisystemic disease characterized by highly variable expression in both age at onset and clinical severity. The manifestations include myotonia, muscle weakness, cataracts, cardiac arrhythmias, frontal baldness, impaired glucose tolerance, and mental retardation (Harper, 1989). DM is the most prevalent adult muscular dystrophy in Europe, North America, India, and North Eastern Asia, with prevalence of $0.2-9.9$ per 100,000 individuals (Araki, 1976; Harper, 1989; Nakagawa et al., 1991). The mutation causing DM has been characterized as an expansion of the unstable CTG trinucleotide repeat in the $3^{\prime}$-untranslated region (UTR) of the DM protein kinase (DMPK) gene located in chromosome 19q13.3 (Brook et al., 1992; Buxton et al., 1992; Fu et al., 1992; Harley et al., 1992a; Mahadevan et al., 1992). Statistical data on DM mutation are essential for genetic counseling. The characteristics of DM dynamic mutation have been reported in English (Harley et al., 1992b, 1993), French (Lavedan et al., 1993), Spanish (Cobo et al., 1993), Canadian (Hunter et al., 1992; Tsilfidis et al., 1992; Barcelo et al., 1993). Australian (Mulley et al., 1993), and American people (Ashizawa et al., 1992, 1993, 1994a; Redman et al., 1993). We previously showed that CTG expansion was also detected in Japanese DM (Yamagata et al., 1992).

In the present study, we analyzed a large sample of Japanese DM families to further appreciate the characteristics of Japanese DM mutation.

\section{MATERIALS AND METHODS}

Families. Blood samples of 351 individuals from 105 Japanese families including 93 DM families (196 affected, 116 unaffected) and 12 muscular disease families (with floppy infants of unknown cause, Duchenne muscular dystrophy, parkinsonism, and amyotrophic lateral sclerosis, etc.) were collected from all over Japan. In our DM families, there were $84 \mathrm{DM}$ parent-child pairs (44 father-child and 40 mother-child). All were Japanese. The clinical diagnosis of DM was based on the diagnostic criteria (Griggs et al., 1989), and we obtained careful histories from patients and their families to document the age of onset. Muscle weakness, myotonia or cataract as first noted by the patient, the parents or the doctor defined the onset of the disease. Other symptoms, such as school difficulties or poor performance in sports, were recorded but were not considered specific enough on retrospective evaluation to mark the onset of DM.

All subjects were referred to us for molecular analysis in a context of presymptomatic, prenatal or confirmative diagnosis. According to severity and the age of onset, we grouped the patients into four different classes: (1) congenital DMonset between $0-1$ year (facial weakness, hypotonia, respiratory distress, and hydram- 
nios, etc.), (2) juvenile onset DM (1-19 year), (3) classical DM (onset $\geqq 20$ year), (4) minimal or subclinical DM-no noted symptoms other than cataracts (onset> 50 year) and asymptomatic obligate carriers.

DNA analysis. High molecular weight DNA was extracted from whole blood, lymphoblastoid cell lines, or chorionic villus samples (CVS) according to standard procedures. The DNA was analyzed with the p5B1.4 probe after restriction enzyme digestion with EcoRI or BglI as previously reported (Shelbourne et al., 1992). PCR analysis was also performed to study both the non-DM individuals and the DM patients showing a small increase of the CTG repeat $(<0.5 \mathrm{~kb})$ on Southern blots (Davies et al., 1992).

Statistical methods. All statistical analyses were carried out with the program package, Stat View (Abacus Concepts, Inc.). It consisted of Wilcoxon rank sums test in a non-parametric analysis, ANOVA (one-way analysis of variance), Bonferroni $t$-test, Pearson's coefficient, and chi-square test with Yates' correction.

\section{RESULTS}

Relationship of CTG repeat size to phenotype of the disease

As was expected, DM-specific CTG repeat expansion was observed. All definite DM patients had repeat expansions, and both healthy individuals and non-DM patients had no expansions. The normal stable upper limit was 35 repeats. Information on the clinical onset of features of DM and CTG mutation was available in a total of 93 affected individuals, from 93 unrelated DM families. Figure 1 shows the relationship of repeat length to age at onset, which indicated strong negative correlation $(r=-0.587, p=0.0001)$. No significant difference was seen when the data were divided by sex (data not shown).

Next, we grouped the patients into four classes-(1) congenital DM, (2) juvenile onset DM, (3) classical DM, and (4) minimal DM, and plotted the CTG repeat length, respectively (Fig. 2). Clinical and molecular data were available in 184 of the families studied. They included 27 congenital DM, 29 juvenile onset DM, 110 classical DM, and 18 minimal DM. An analysis of variance was performed (ANOVA and Bonferroni $t$-test). While there was overlap of repeat sizes between patient categories, there was nevertheless a correlation of increasing repeat size with disease severity. The largest repeat sizes on average belonged to congenital DM, and the smallest did to minimal DM. Figure 2 showed that there was a significant difference in repeat size among the four groups $(p<0.001)$.

\section{Intergenerational differences in $C T G$ repeat size}

To investigate the relationship between CTG expansion and anticipation, we studied 84 parent-child pairs in which both parent and child had the expansion. In $76(90 \%)$ of the 84 pairs, an increase in CTG repeat size was seen. In contrast, $2(2 \%)$ of the 84 pairs showed a definite decrease between two generations, but 


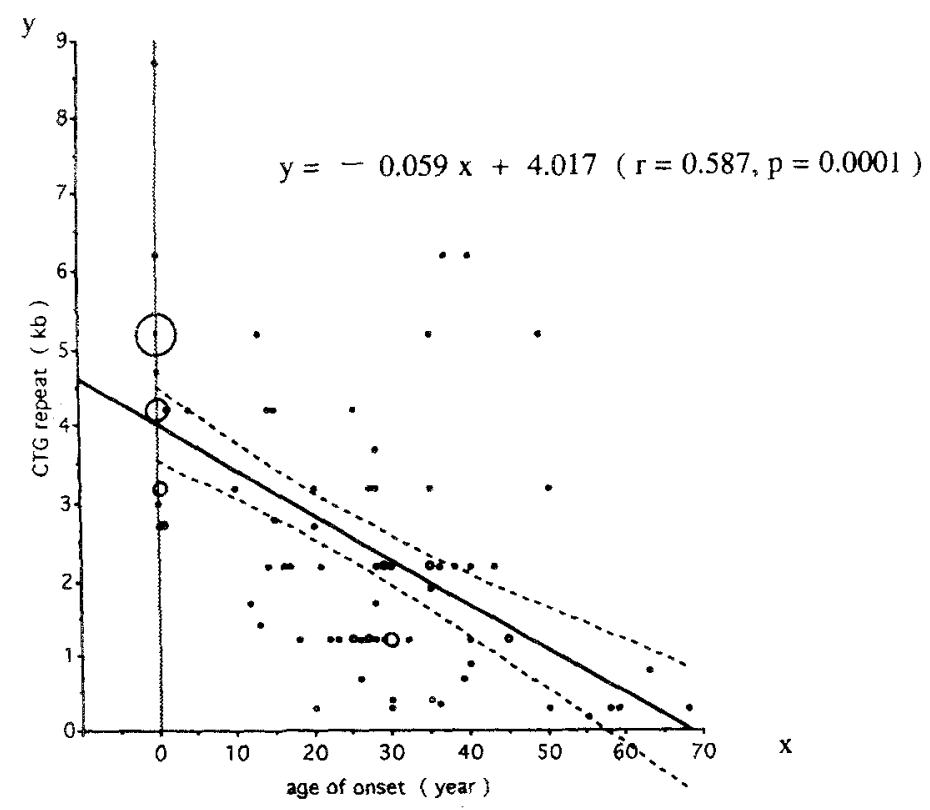

Fig. 1. Correlation of ages of onset with expansions of the CTG repeat. A Pearson's correlation coefficient of $\mathrm{r}=-0.587, \mathrm{p}=0.0001 \quad(\mathrm{n}=93)$ was obtained. The figure displays a regression line and $95 \%$ confidence bands for the true mean of $Y$.

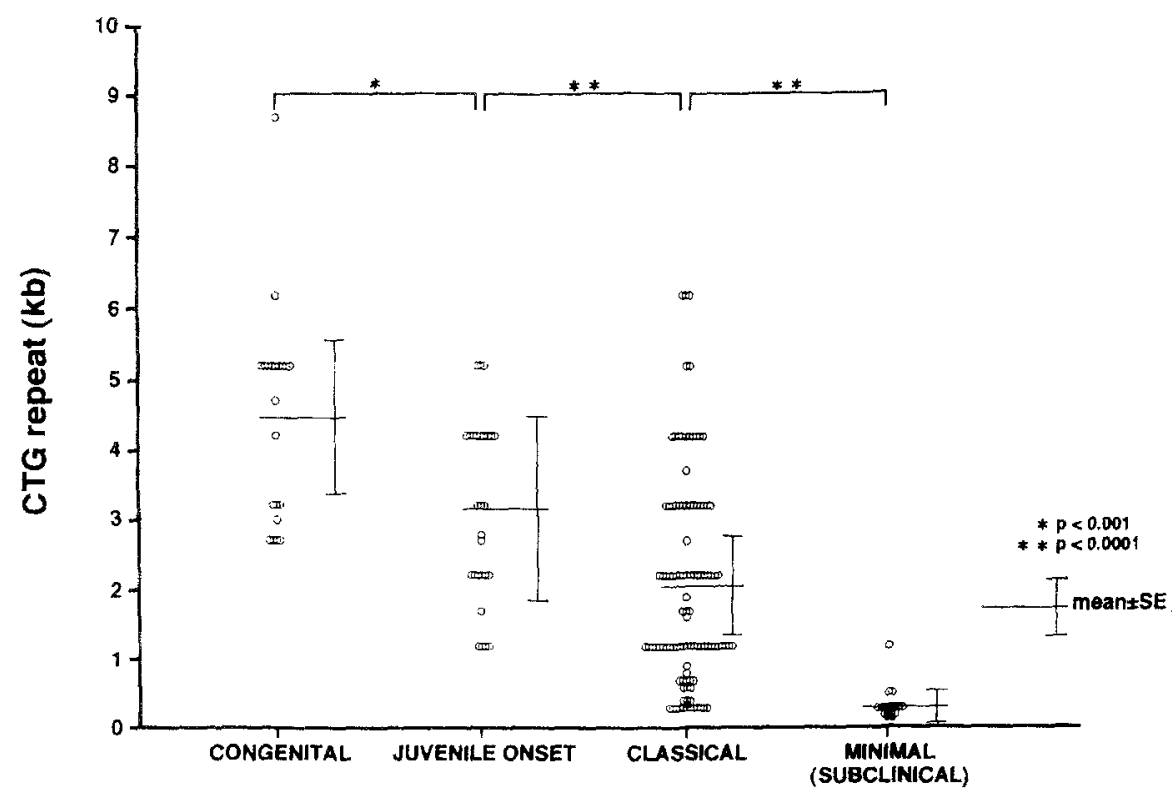

Fig. 2. Size of the CTG repeat and the age of onset of disease in $184 \mathrm{DM}$ patients. The categories for age of onset are congenital for symptoms up to 1 year of life, juvenile for onset from 1 to less than 20 years, classical at 20 years or older, and minimal for no noted symptoms other than cataract. 
(A)
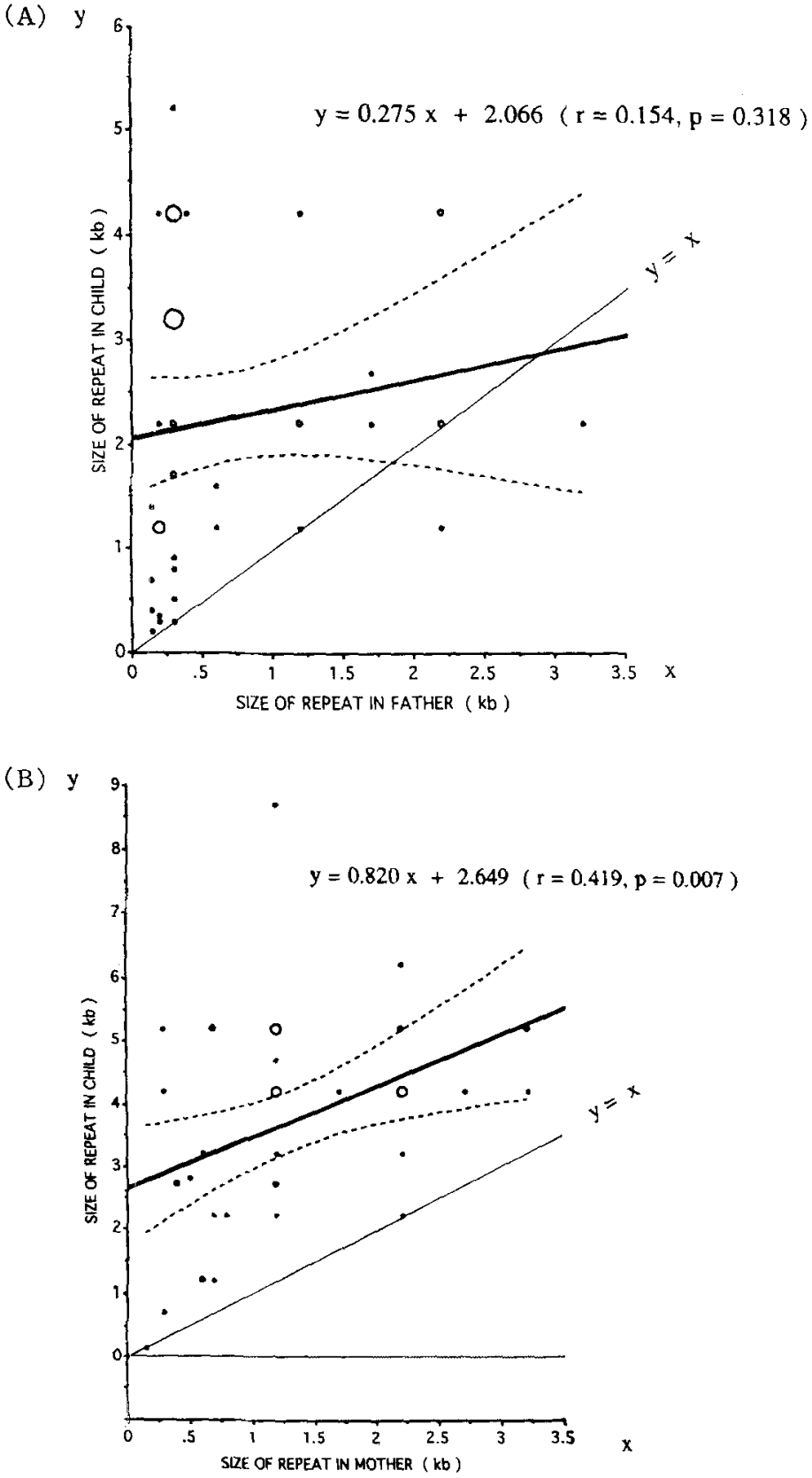

Fig. 3. CTG repeat length for 84 parent-child pairs. (A) 44 father-child pairs. (B) 40 mother-child pairs. Points above the diagonal indicate anticipation (repeat size greater in child than in parent), and points below the diagonal indicate contraction. The figures display regression lines and $95 \%$ confidence bands for the true mean of $Y$.

Vol. 39, No. 3, 1994 
in one of two cases, age of onset was earlier in the child than in the father. The exceptions in age of onset may be explained by bias in ascertainment, which was often based on the patient's recollection of his first awareness of symptoms.

For father-child pairs and mother-child pairs, repeat size is shown in Fig. 3 (A), and (B), respectively. Both analyses showed a weak positive correlation between parent and child (father-child: $r=0.154, p=0.32$; mother-child: $r=0.419$, $p=0.007)$. The increase in size of repeat was greater in transmission from females than in one from males. Almost all cases of congenital DM were transmitted by affected mothers, except one pedigree (Ohya et al., 1994).

\section{Parental age effect on DM mutation}

To examine whether older parental age influences upon fresh DM mutation, we compared CTG repeat length and parental age at birth. A Pearson's correlation coefficient of $r=0.095, p=0.61$ ( $Y$ : intergenerational variation $(\mathrm{kb}), X$ : father's age at birth (year)), and $r=0.178, p=0.32$ ( $Y$ : intergenerational variation $(\mathrm{kb}$ ), $X$ : mother's age at birth (year)) were obtained. Neither paternal nor maternal age effect was observed.

\section{DISCUSSION}

We investigated large DM families to obtain prognostic information. There were striking similarities between our findings in the Japanese population and those in Caucasians: there was a strong correlation between the size of the repeat and the age of onset. We confirmed previous reports for such a correlation. However, we also found clinical variation without a corresponding variation in repeat length, and vice versa. As Harley et al. (1993) has speculated, the overlap in the range of repeat sizes between congenital cases and others indicates that repeat size is not the only feature determining congenital DM. Factors, such as somatic mosaicism and/or environmental factors may contribute to the onset or severity of the phenotype. Thus, it is important to take into account that there are exceptions, especially in classical DM, when performing DNA analysis for evaluation of prognosis.

The tendency for anticipation is strikingly demonstrated in Fig. 3, with only two instances of contraction in repeat size in the offspring. However, one of the two revealed earlier onset age in the offspring regardless of contraction (father $3.2 \mathrm{~kb}$, classical DM; daughter $2.2 \mathrm{~kb}$, juvenile onset $\mathrm{DM}$ ). Ashizawa et al. (1994b) examined 1,489 DM parent-offspring pairs and reported that the contraction occurred in $10 \%$ paternal transmissions, and $3 \%$ maternal transmissions. Surprisingly, $48 \%$ of such cases showed anticipation, earlier age of onset in successive generations. We confirmed such a discrepancy.

In the present study, DNA expansion was analyzed mostly in lymphocytes, and it is probable that different degrees of expansion may cause varying pheno- 
typic effects in relevant tissues, such as muscle. For evaluation of severity or prognosis, it may be necessary to know the properties of the protein involved, which is predicted to belong the protein kinase family. To date, the effect of expansion of the repeat in the $3^{\prime}$-UTR of the gene has been suggested to be quantitatively related either to mRNA stability or to regulation of transcription of neighboring genes.

Jones et al. (1975) reported a paternal age effect in some autosomal dominant diseases. Brown (1979) reviewed autosomal dominant inheritance (most cases resulting from new mutation) because of the paternal age effect and the low frequency of parental consanguinity. To date, progeria has been considered to have parental age effect. DM is one of the progeroid syndromes. However, in the present study we did not detect a paternal or maternal age effect for intergenerational changes of CTG repeat size.

Finally, molecular data will allow improved diagnosis of the disease and it may also help with the evaluation of the risk of disease in the progeny of at risk individuals.

Acknowledgments We thank Dr. T. Ikeda, Dr. J. Kang, Dr. I. Kondo, Dr. Y. Muto, Dr. T. Namikawa, Dr. S. Onogi, Dr. K. Ohya, Dr. K. Saida, Dr. K. Saito, Dr. N. Tachi, Dr. T. Takayanagi, and Dr. M. Ukita for their contributions to family study. We are grateful to Dr. K. Johnson who kindly provided probe p5B1.4. This work was supported by grant-in-aid for scientific research in priority areas from the Ministry of Education, Science and Culture and the Ministry of Health and Welfare of Japan.

\section{REFERENCES}

Araki S (1976): Myopathy in Kuroiwa, Kondo (eds) Neuroepidemiology, Igaku-shoin, Tokyo, pp 319-338

Ashizawa T, Dubel JR, Dunne PW, Dunne CJ, Fu Y-H, Pizzuti A, Caskey CT, Boerwinkle E, Perryman MB, Epstein HF, Hejtmancik JF (1992): Anticipation in myotonic dystrophy. II. Complex relationship between clinical findings and structure of the GCT repeat. Neurology 42: $1877-1883$

Ashizawa T, Dubel JR, Harati Y (1993): Somatic instability of CTG repeat in myotonic dystrophy. Neurology 43: 2674-2678

Ashizawa T, Dunne PW, Ward PA, Seltzer WK, Richards CS (1994a): Effects of the sex of myotonic dystrophy patients on the unstable triplet repeat in their affected offspring. Neurology 44: $120-122$

Ashizawa T, Anvret M, Baiget M, Barcelo JM, Brunner H, Cobo AM, Dallapiccola B, Fenwick RG Jr, Grandell U, Harley H, Junien C, Koch MC, Korneluk RG, Lavedan C, Miki T, Mulley JC, Lopez de Munain A, Novelli G, Roses AD, Seltzer WK, Shaw DJ, Smeets H, Sutherland GR, Yamagata H, Harper PS (1994b): Characteristics of intergenerational contractions of the CTG repeat in myotonic dystrophy. Am J Hum Genet 54: 414-423

Barcelo JM, Mahadevan MS, Tsilfidis C, MacKenzie AE, Korneluk RG (1993): Intergenerational stability of the myotonic dystrophy protomutation. Hum Mol Genet 2: 705-709

Brook JD, MaCurrach ME, Harley HG, Buckler AJ, Church D, Aburatani H, Hunter K, Stanton VP, Thirion JP, Hudson T, Sohn R, Zemelman B, Snell RG, Rundle SA, Crow S, Davies J, Shelbourne P, Buxton J, Jones C, Juvonen V, Johnson K, Harper PS, Shaw DJ, Housman DE (1992): Molecular basis of myotonic dystrophy: expansion of a trinucleotide (CTG) repeat

Vol. 39, No. 3, 1994 
at the $3^{\prime}$ end of a transcript encoding a protein kinase family member. Cell 68: 799-808

Brown WT (1979): Human mutations affecting aging-A review. Mech Aging Dev 9: 325-336

Buxton J, Shelbourne P, Davies J, Jones C, Van Tongeren T, Aslanidis C, de Jong P, Jansen G,

Anvret M, Riley B, Williamson R, Johnson K (1992): Detection of an unstable fragment of DNA specific to individuals with myotonic dystrophy. Nature 355: $547-548$

Cobo AM, Baiget M, Lopez de Munain A, Poza JJ, Emparanza JI, Johnson K (1993): Sex-related difference in intergenerational expansion of myotonic dystrophy gene. Lancet 341: 1159-1160

Davies J, Yamagata H, Shelbourne P, Buxton J, Ogihara T, Nokelainen P, Nakagawa M, Williamson R, Johnson K, Miki T (1992): Comparison of the myotonic dystrophy associated CTG repeat in European and Japanese populations. J Med Genet 29: 766-769

Fu Y-H, Pizzuti A, Fenwick RG Jr, King J, Rajnarayan S, Dunne PW, Dubel J, Nasser GA, Ashizawa T, de Jong P, Wieringa B, Korneluk R, Perryman MB, Epstein HF, Caskey CT (1992): An unstable triplet repeat in a gene related to myotonic muscular dystrophy. Science 255: 12561258

Griggs RC, Wood DS, the Working Group on the Molecular Defect in Myotonic Dystrophy (1989): Criteria for establishing the validity of genetic recombination in myotonic dystrophy. Neurology 39: 420-421

Harley HG, Brook JD, Rundle SA, Crow S, Reardon W, Buckler AJ, Harper PS, Housman DE, Shaw DJ (1992a): Expansion of an unstable DNA region and phenotypic variation in myotonic dystrophy. Nature 355: 545-546

Harley HG, Rundle SA, Reardon W, Myring J, Crow S, Brook JD, Harper PS, Shaw DJ (1992b): Unstable DNA sequence in myotonic dystrophy. Lancet 339: 1125-1128

Harley HG, Rundle SA, MacMillan JC, Myring J, Brook JD, Crow S, Reardon W, Fenton I, Shaw DJ, Harper PS (1993): Size of the unstable CTG repeat sequence in relation to phenotype and parental transmission in myotonic dystrophy. Am J Hum Genet 52: 1164-1174

Harper PS (1989): Myotonic dystrophy. 2nd ed. WB Saunders, Philadelphia

Hunter, A, Tsilfidis C, Mettler G, Jacob P, Mahadevan M, Surh L, Korneluk R (1992): The correlation of age of onset with CTG trinucleotide repeat amplification in myotonic dystrophy. J Med Genet 29: $774-779$

Jones KL, Smith DW, Harvey MAS, Hall BD, Quan L (1975): Older paternal age and fresh gene mutation: data on additional disorders. J Pediatr 86: 84-88

Lavedan C, Hofmann-Radvanyi H, Shelbourne P, Rabes J-P, Duros C, Savoy D, Dehaupas I, Luce S, Johnson K, Junien C (1993): Myotonic dystrophy: size- and sex-dependent dynamics of CTG meiotic instability, and somatic mosaicism. Am J Hum Genet 52: 875-883

Mahadevan M, Tsilfidis C, Sabourin L, Shutler G, Amemiya C, Jansen G, Neville C, Narang M, Barcelo J, O'Hoy K, Leblond S, Earle-Macdonald J, de Jong PJ, Wieringa B, Korneluk RG (1992): Myotonic dystrophy mutation: an unstable CTG repeat in the $3^{\prime}$ untranslated region of the gene. Science 255: 1253-1255

Mulley JC, Staples A, Donnelly A, Gedeon AK, Hecht BK, Nicholson GA, Haan EA, Sutherland GR (1993): Expansion for exclusive maternal origin for congenital form of myotonic dystrophy. Lancet 341 : 236-237

Nakagawa M, Nakahara K, Yoshidome H, Suehara M, Higuchi I, Fujiyama J, Nakamura A, Kubota R, Takenaga S, Arahata K, Asano J, Osame M (1991): Epidemiology of progressive muscular dystrophy in Okinawa, Japan. Neuroepidemiology 10: 185-191

Ohya K, Tachi N, Chiba S, Sato T, Kikuchi K, Yamagata H, Miki T (1994): Congenital myotonic dystrophy transmitted from an asymptomatic father with a DM-specific gene. Neurology (in press)

Redman JB, Fenwick RG Jr, Fu Y-H, Pizzuti A, Caskey T (1993): Relationship between parental trinucleotide GCT repeat length and severity of myotonic dystrophy in offspring. JAMA 269: 1960-1965 
Shelbourne P, Winqvist R, Kunert E, Davies J, Leisti J, Thiele H, Bachmann H, Buxton J, Williamson B, Johnson K (1992): Unstable DNA may be responsible for the incomplete penetrance of the myotonic dystrophy phenotype. Hum Mol Genet 1: 467-473

Tsilfidis C, MacKenzie AE, Mettler G, Barcelo J, Korneluk RG (1992): Correlation between CTG repeat length and frequency of severe congenital myotonic dystrophy. Nature Genet 1: 192195

Yamagata H, Miki T, Ogihara T, Nakagawa M, Higuchi I, Osame M, Shelbourne P, Davies J, Johnson K (1992): Expansion of unstable DNA region in Japanese myotonic dystrophy patients. Lancet 339: 692

Vol. 39, No. 3, 1994 